\title{
Meat yield characteristics of broiler fed different levels of palm oil
}

\author{
GB Das ${ }^{1}$, ME Hossain ${ }^{1 *}$, MM I slam¹, MA Akbar ${ }^{2}$
}

${ }^{1}$ Department of Animal Science and Nutrition, Faculty of Veterinary Medicine; Chittagong Veterinary and Animal Sciences University, Khulshi, Chittagong 4225; ${ }^{2}$ Department of Animal Nutrition, Bangladesh Agricultural

University, Mymensingh 2202, Bangladesh

\begin{abstract}
Seven hundred fifty day old unsexed broiler chicks were used in a 35-d trial to examine the effect of supplementing different levels of palm oil on lean meat yield of broilers. The chicks were randomly distributed following a completely randomized design in five treatment groups having three replications per treatment. Each treatment had 150 birds with 50 birds per replicate. Five diets were formulated using locally available ingredients as diet without oil, diet containing $2.0 \%, 3.0 \%, 4.0 \%$ and $5 \%$ palm oil. Results indicated that weight gain of broilers differed significantly $(p<0.05)$ among the treatment groups at $2^{\text {nd }} w k$. The weight gain of $4 \%$ palm oil group was higher $(p<0.05)$ than $5 \%$ dietary oil group at $2^{\text {nd }} w k$. At $5^{\text {th }} w k$, weight gain of without oil and $5 \%$ oil groups were similar $(p>0.05)$. Feed intake significantly $(p<0.05)$ differed at $2^{\text {nd }} w k$. Broiler that received $5 \%$ dietary palm oil group consumed the least amount of feed compared to others. No significant differences were found among the treatments in whole experimental period for feed conversion ratio. The meat yield characteristics did not differ $(p>0.05)$ among the broilers receiving different levels of palm oil in diets except gizzard, wing meat and dark meat. Supplementation of oil resulted in significantly $(p<0.05)$ increased dark meat weight at 3\% level. Dressed yield of broilers had an increasing trend at increased level of palm oil supplementation up to $4 \%$. However, at $5 \%$ supplementation dressed yield was lowest. Similar results were also observed in breast meat. Thigh meat was progressively increased for supplementation of oil up to $3 \%$ level, at higher level it tended to decrease.
\end{abstract}

Key words: Broiler, feed conversion, feed intake, meat yield, palm oil, weight gain

Bangladesh Animal Husbandry Association. All rights reserved. Bang. J. Anim. Sci. 2014. 43 (2): 112-117

\section{I ntroduction}

Broiler farming has been increasing steadily throughout the country. At present, there are about 0.15 million poultry farmers in the country and 6 million livelihoods directly depends on poultry industry (Rahman 2000). In broiler industry the main intention is to ensure maximum marketable weight of the broilers within least possible time. The broiler is known to be an efficient food converter of low quality animal feed into high quality human food. However, tremendous improvement already recorded in broilers by genetic approaches and balancing diet. Therefore, broiler raisers are always interested to different approaches for better growth and economic production. To achieve optimum economic benefit within short time it is important to provide balanced diet to the commercial broilers. This type of ration must be formulated with high level of metabolizable energy and crude protein. To maintain high metabolizable energy level there is no substitute for use of either animal fat or vegetable oil. Therefore, it is important to consider that the subsequent consequences of the supplemental energy sources on dressing percentage and lean meat yield of the dressed broilers. If supplemental energy level obtained from either animal fat or vegetable oil influence rapid weight gain by deposition of abdominal fat then the consumer will be deprived from lean meat. Under such circumstances, consumers will pay for meat and incautiously they will buy abdominal fat which is harmful for human health. The current study was, therefore, undertaken to examine the effect of supplementing different levels of palm oil on lean meat yield of broilers.

\section{Materials and methods}

The study was carried out under the Department of Animal Science and Nutrition at Chittagong 
Veterinary and Animal Sciences University Poultry Farm, Chittagong, Bangladesh during the period from February to March, 2012. Seven hundred fifty day old, unsexed, commercial broiler chicks were used for the study purpose. Initial average body weight of the birds was $40.1 \mathrm{~g}$. A bamboo stilted type house was constructed for rearing broiler. The house was covered with corrugated sheet. The floor of the house was $90 \mathrm{~cm}$ above the ground. Forty five $\mathrm{cm}$ of the sidewall of the house from floor was made of bamboo and the remaining portion was made of wire net to facilitate proper ventilation. The floor of the house was made of bamboo splits on which fresh dry rice husk was used as litter material at a depth of $4.5 \mathrm{~cm}$. Old litter materials were removed and new litter was replaced twice a week in the pen. Arrangement of floor for rearing broilers was made according to treatments and replications. Compartments were selected for treatment in an unbiased way. The floor of the house was divided by wire net into 12 compartments to maintain desired replication. Birds were brooded under single-tired electric brooder at $95^{\circ} \mathrm{F}, 90^{\circ} \mathrm{F}, 85^{\circ} \mathrm{F}$ and $80^{\circ} \mathrm{F}$ for the $1^{\text {st }}$, $2^{\text {nd }}, 3^{\text {rd }}$ and $4^{\text {th }}$ week, respectively by enclosing the compartments with chick guard. The birds were exposed to continuous lighting. Room temperature and humidity was maintained using 200 watt incandescent lamps and exhaust fans.

Experimental diets were dry mash type. Ground feed ingredients, vitamin mineral premix and feed additives (Renata Itd., Bangladesh) used in the ration (Table 1) were purchased from a local market. The diets were prepared by hand mixing. At first, major ingredients were thoroughly mixed then micro-ingredients were added. Birds had unrestricted access to feed and water. Feed and water were supplied to the birds by plastic hanging feeder and bell type drinker. Five rations designated as $T_{0}, T_{1}, T_{2}, T_{3}$ and $T_{4}$ were formulated where $T_{1}, T_{2}, T_{3}$ and $T_{4}$ were supplemented with $2.0 \%, 3.0 \%, 4.0 \%$ and $5.0 \%$ palm oil and $\mathrm{T}_{0}$ was a without oil group. These rations were supplied to four groups of birds randomly. Detailed proportion of the feed ingredients in different rations is given in Table 1. Nutrient density in the experimental diet was maintained according to Singh (1980). Formulated diets were analyzed as per AOAC (1997). The starter diet was fed for the first two weeks and the finisher diet was fed for the remaining periods.

Table 1. Composition of the diets

\begin{tabular}{|c|c|c|c|c|c|c|c|c|c|c|}
\hline \multirow{3}{*}{ Ingredients (\%) } & \multicolumn{10}{|c|}{ Dietary treatments } \\
\hline & \multicolumn{2}{|c|}{ Control } & \multicolumn{2}{|c|}{ 2.0\% Palm oil } & \multicolumn{2}{|c|}{ 3.0\% Palm oil } & \multicolumn{2}{|c|}{ 4.0\% Palm oil } & \multicolumn{2}{|c|}{$5.0 \%$ Palm oil } \\
\hline & Starter & Finisher & Starter & Finisher & Starter & Finisher & Starter & Finisher & Starter & Finisher \\
\hline Maize & 63.20 & 65.60 & 63.30 & 66.50 & 60.20 & 62.60 & 57.25 & 59.50 & 52.00 & 57.00 \\
\hline Rice polish & 2.02 & 2.27 & 1.22 & 1.00 & 2.02 & 2.27 & 2.77 & 3.27 & 6.37 & 3.77 \\
\hline Palm oil & - & - & 2.00 & 2.00 & 3.00 & 3.00 & 4.00 & 4.00 & 5.00 & 5.00 \\
\hline Soybean meal & 29.50 & 26.00 & 25.80 & 23.37 & 29.50 & 26.00 & 31.25 & 27.50 & 30.90 & 27.50 \\
\hline Protein concentrate ${ }^{1}$ & 2.75 & 3.50 & 5.25 & 5.00 & 2.75 & 3.50 & 0.00 & 2.50 & 0.00 & 0.00 \\
\hline Meat \& Bone meal ${ }^{2}$ & 0.50 & 0.50 & 0.50 & 0.50 & 0.50 & 0.50 & 2.50 & 0.50 & 3.00 & 4.00 \\
\hline Limestone $^{3}$ & 0.80 & 1.00 & 0.70 & 0.60 & 0.80 & 1.00 & 1.00 & 1.50 & 1.50 & 1.50 \\
\hline Dicalcium phosphate 4 & 0.50 & 0.40 & 0.50 & 0.30 & 0.50 & 0.40 & 0.50 & 0.50 & 0.50 & 0.50 \\
\hline L-Lysine & 0.05 & 0.05 & 0.05 & 0.05 & 0.05 & 0.05 & 0.05 & 0.05 & 0.05 & 0.05 \\
\hline DL Methionine & 0.16 & 0.16 & 0.16 & 0.16 & 0.16 & 0.16 & 0.16 & 0.16 & 0.16 & 0.16 \\
\hline Coccidiostat & 0.02 & 0.02 & 0.02 & 0.02 & 0.02 & 0.02 & 0.02 & 0.02 & 0.02 & 0.02 \\
\hline Common salt & 0.25 & 0.25 & 0.25 & 0.25 & 0.25 & 0.25 & 0.25 & 0.25 & 0.25 & 0.25 \\
\hline \multicolumn{11}{|l|}{ Calculated values } \\
\hline ME (kcal/kg) & 2902 & 2933 & 3021 & 3058 & 3022 & 3052 & 3018 & 3055 & 3023 & 3062 \\
\hline $\mathrm{CP}(\%)$ & 21.25 & 20.37 & 20.99 & 20.02 & 20.97 & 20.09 & 21.00 & 20.01 & 21.06 & 20.05 \\
\hline $\mathrm{CF}(\%)$ & 3.30 & 3.17 & 3.08 & 2.97 & 3.23 & 3.10 & 3.29 & 3.18 & 3.46 & 3.18 \\
\hline EE $(\%)$ & 2.90 & 3.00 & 4.94 & 4.90 & 5.85 & 5.93 & 6.93 & 6.95 & 8.39 & 8.22 \\
\hline $\mathrm{Ca}(\%)$ & 0.76 & 0.84 & 0.85 & 0.75 & 0.75 & 0.84 & 0.77 & 0.99 & 0.99 & 1.02 \\
\hline $\mathrm{P}(\%)$ & 0.64 & 0.63 & 0.67 & 0.62 & 0.63 & 0.62 & 0.60 & 0.62 & 0.63 & 0.61 \\
\hline
\end{tabular}

${ }^{1} \mathrm{DM}=92.5 \% ; \quad \mathrm{ME}=2900 \mathrm{kcal} / \mathrm{kgDM} ; \mathrm{CP}=60.0 \% ; \mathrm{CF}=3.0 \% ; \quad \mathrm{EE}=13.0 \% ; \quad \mathrm{Ash}=24.0 \% ; \quad \mathrm{Ca}=6.5 \% ; \mathrm{P}=2.5 \% ;$ Lysine $=7.0 \%$; Methionine $=2.0 \%$; ${ }^{2} \mathrm{DM}=91.5 \% ; \quad \mathrm{ME}=2111 \mathrm{kcal} / \mathrm{kgDM} ; \mathrm{CP}=53.8 \%$; $\mathrm{CF}=6.2 \%$; $\mathrm{EE}=12.0 \%$; Ash $=28.0 \% ; \mathrm{Ca}=11.3 \% ; \mathrm{P}=5.39 \% ;$ Lysine $=3.72 \% ;$ Methionine $=0.75 \% ;{ }^{3} \mathrm{DM}=98.9 \% ; \mathrm{Ca}=35.8 \% ; \mathrm{P}=0.02 \%$; ${ }^{4} \mathrm{DM}=98.0 \% ; \mathrm{Ca}=24.3 \% ; \mathrm{P}=18.2 \% ;{ }^{5} \mathrm{~T}_{0}=$ Diet without oil; $\mathrm{T}_{1}=$ Diet containing $2.0 \%$ palm oil; $\mathrm{T}_{2}=$ Diet containing $3.0 \%$ palm oil; $\mathrm{T}_{3}=$ Diet containing $4.0 \%$ palm oil; $\mathrm{T}_{4}=$ Diet containing $5.0 \%$ palm oil 


\section{Palm oil in broiler feed}

The slated floor and cages were cleaned and disinfected with phenyl solution. The room was fumigated overnight using potassium permanganate and formaldehyde. Feeders and drinkers were cleaned and disinfected with phenyl solution and dried and left for 3 days before arrival of the chicks. Foot bath containing potassium permanganate was placed in front of the shed. The birds were given New castle and Gumboro disease vaccine ( $\mathrm{ACl}$ Itd., Bangladesh) on the $4^{\text {th }}$ and $10^{\text {th }}$ day followed by a booster dose on 20th and $25^{\text {th }}$ day. No outbreak of infectious diseases was found throughout the whole experimental period.

At the end of $4^{\text {th }}$ and $5^{\text {th }}$ weeks of the experiment, 12 birds from each replication weighing close to the average of the pen were selected and slaughtered by cervical dislocation for processing. Feeders and drinkers were withdrawn from the pens 4 hours prior to slaughtering to empty the digestive system with less chance of damaging the intestines and contaminating the carcass with fecal materials. Carcass was subjected to dissection following Jones (1984) method. Carcass weight was recorded after removal of feather, feet, head and viscera. Hot carcass weight was recorded immediately after evisceration.

Table 2. Vaccination schedule for broilers

\begin{tabular}{ccccl}
\hline $\begin{array}{c}\text { Age } \\
\text { (days) }\end{array}$ & $\begin{array}{c}\text { Name of } \\
\text { diseases }\end{array}$ & $\begin{array}{c}\text { Name of } \\
\text { vaccine }\end{array}$ & $\begin{array}{c}\text { Type of } \\
\text { vaccine }\end{array}$ & Route \\
\hline 5 & Ranikhet & BCRDV & Live & Eye drop \\
12 & Gumboro & Gumboro vaccine & Live & Eye drop \\
20 & Ranikhet & BCRDV (booster) & Live & Eye drop \\
25 & Gumboro & Gumboro (booster) & Live & Eye drop \\
\hline
\end{tabular}

The experiment was carried out following completely randomized design (Gomez and Gomez, 1984). Birds in individual replicate were treated as the experimental unit and diet was treated as the factor. Total 750 birds were weighed and randomly divided into five treatment groups. Each treatment was divided into three replicates. Each group had 150 birds having 50 birds per replicate. Data related to weight gain, feed intake, FCR and carcass characteristics were compiled by using Microsoft excel 2007 and analyzed for ANOVA by using Stata (2009) and SPSS (2007). Means showing significant differences were compared by Duncan's New Multiple Range Test (Duncan 1955).

\section{Results and discussion}

Live weight gain of broiler received different dietary levels (\%) of palm oil is given in Table 3. Weight gain of broilers differed significantly $(p<0.05)$ among the treatments at 2 nd week of age. The weight gain of $4 \%$ palm oil group was higher $(p<0.05)$ than that on $5 \%$ dietary oil at 2 nd week of age. At the 5 th week weight gains of without oil and 5\% oil almost similar. From the results of palm oil supplementation on live weight gain of broilers it as clear that supplementation up to $4 \%$ had considerable non-significant ( $p>0.05)$ positive effect on this parameter of the broilers. Supplementation of oil at further higher level ( $5 \%$ palm oil) had depressing effect on live weight gain at every week throughout the experimental period. Results also showed that at the 1st week of age of broilers, there was no significant effect of oil supplementation and it might be the adjustment period in the utilization of oil which perhaps has been minimized to show significant $(p<0.05)$ increasing live weight gain of the broilers in the subsequent weeks. This result coincides with the findings of Nwoche et al. (2003) who found that $4 \%$ inclusion level of palm oil showed the highest $(p<0.05)$ body weight gain. Hake et al. (2005) reported that palm oil has positive effect on live weight of broiler. Table 4 shows that broilers fed on different levels of palm oil gained cumulative weight similar to $0 \%$ oil. The results of this study indicated that weight gain of $0 \%$ and $5 \%$ dietary palm oil group are similar but lower than the rest of the groups. So, it is not judicious to use high level of palm oil in broiler ration for better live weight gain.

Table 3. Live weight gain ( $g / b i r d / w k)$ of broilers fed different levels of palm oil

\begin{tabular}{|c|c|c|c|c|c|c|}
\hline \multirow{3}{*}{$\begin{array}{l}\text { Age } \\
\text { (wk) }\end{array}$} & \multicolumn{5}{|c|}{ Dietary treatments } & \multirow{3}{*}{$\begin{array}{l}\text { Sig. } \\
\text { level }\end{array}$} \\
\hline & \multirow{2}{*}{ Control } & \multirow{2}{*}{$\begin{array}{c}2.0 \% \\
\text { Palm oil }\end{array}$} & \multirow{2}{*}{$\begin{array}{c}3.0 \% \\
\text { Palm oil }\end{array}$} & \multirow{2}{*}{$\begin{array}{c}.0 \% \\
\text { Palm oil }\end{array}$} & \multirow{2}{*}{$\begin{array}{c}.0 \% \\
\text { Palm oil }\end{array}$} & \\
\hline & & & & & & \\
\hline 1 & 93.22 & 96.33 & 102.88 & 100.27 & 94.85 & NS \\
\hline 2 & $240.07^{a b}$ & $237.88^{a b}$ & $244.35^{a}$ & $252.73^{a}$ & $223.07^{b}$ & * \\
\hline 3 & 381.81 & 392.58 & 397.23 & 412.95 & 374.33 & NS \\
\hline 4 & 473.46 & 486.73 & 523.14 & 512.70 & 497.88 & NS \\
\hline 5 & 477.17 & 529.83 & 464.03 & 465.63 & 477.82 & NS \\
\hline \multicolumn{7}{|c|}{ Cumulative weight gain } \\
\hline 1 to 4 & 1188.32 & 1213.53 & 1267.61 & 1278.65 & 1190.13 & NS \\
\hline 1 to 5 & 1665.74 & 1743.37 & 1731.64 & 1744.28 & 1667.95 & NS \\
\hline
\end{tabular}

Means with different superscript(s) in the same row differed significantly; NS, non-significant; *, p<0.05) 
Differences in feed intake among $0,2,3,4$ and $5 \%$ palm oil groups were found significant $(p<0.05)$ at 2 nd week of age. Broilers that received $5 \%$ dietary palm oil consumed the lowest amount of feed (333.33g) compared to others. Highly significant $(p<0.01)$ differences in feed intake among different groups were also found at 4th week of age, but there were no significant differences among different groups at 3 and 5th week of the trial. Cumulative feed intake was $(p<0.05)$ higher on $4 \%$ dietary palm oil group during 4th week (Table 4). Supplementation of energy from palm oil gave an interesting result as regards feed intake of broilers. At the 1st week, feed intake was similar $(p>0.05)$ in all supplemented group compared with without oil. However, in 2nd week intake of feed drastically $(p<0.05)$ fell in the group having $5 \%$ oil and showed all other groups similar including without oil. This clearly indicated the depressing effect of high level of supplementation on feed intake. This depressing effect of $5 \%$ supplementation continued up to 5 th weeks. It is interesting that all other lower levels of supplementation (2, 3 and $4 \%$ ) showed higher feed intake than that of without oil. Among the lower level of supplementation, $4 \%$ showed the highest feed intake. This result is consistent with the findings of Nwoche et al. (2003), who found that feed intake was highest $(p<0.05)$ at $4 \%$ inclusion level of palm oil in broiler diet and also observed a depression $(p<0.05)$ in the feed intake at $6 \%$ level. Total feed intake of all treated groups was higher than that of without oil except $5 \%$ oil group. This was probably for increased level of energy in the diet as supported by Franco et al. (1995). Olorede and Longe (1999) reported that supplementation of palm oil in broiler diet improved feed intake which is relevant to the present study.

Feed conversions (FC) of broilers under different dietary treatments are presented in Table 5 . The feed conversion differed significantly $(p<.0 .05)$ among the treatments at 2 nd week of age. The best weekly FC was observed in $4 \%$ dietary palm oil supplemented group at 1,2 and 3rd week and broilers on $5 \%$ palm oil had better FC than $3 \%$ and $4 \%$ oil group at 4 and 5 th week of age. However, no significant differences were found throughout the experimental period. The differences observed among the without oil and $2,3,4$ and $5 \%$ palm oil diets were not significant. Cumulative FC of broilers is also given in the same table showing no significant difference among dietary treatments but it was observed that increasing level of palm oil resulted in better FC than the without oil in most of the cases.

Table 4. Feed intake ( $g /$ broiler) of broilers fed different levels of palm oil

\begin{tabular}{|c|c|c|c|c|c|c|}
\hline \multirow{3}{*}{$\begin{array}{l}\text { Age } \\
\text { (wk) }\end{array}$} & \multicolumn{5}{|c|}{ Dietary treatments } & \multirow{3}{*}{ Sig. } \\
\hline & \multirow{2}{*}{ Control } & $2.0 \%$ & $3.0 \%$ & $4.0 \%$ & $5.0 \%$ & \\
\hline & & Palm oil & Palm oil & Palm oil & Palm oil & \\
\hline 1 & 159.17 & 152.42 & 155.32 & 154.25 & 144.77 & NS \\
\hline 2 & $375.05^{a}$ & $375.85^{a}$ & $370.17 a$ & $381.72^{\mathrm{a}}$ & $333.33^{b}$ & * \\
\hline 3 & 675.03 & 694.98 & 692.03 & 692.96 & 710.25 & NS \\
\hline 4 & $936.38^{a b}$ & $997.17 \mathrm{bc}$ & $1000.62^{b c}$ & $1035.22^{c}$ & $864.67^{a}$ & ** \\
\hline 5 & 1051.12 & 1058.01 & 1106.42 & 1008.7 & 1093.75 & NS \\
\hline \multicolumn{7}{|c|}{ Cumulative feed intake } \\
\hline 1 to 4 & $2145.62^{a b}$ & $2169.96^{a}$ & $2218.13^{a}$ & $2264.15^{a}$ & $2053.02^{b}$ & * \\
\hline 1 to 5 & 3181.55 & 3260.10 & 3307.43 & 3279.24 & 3152.42 & NS \\
\hline
\end{tabular}

Means with different superscript(s) in the same row differed significantly; *, $p<0.05 ;{ }^{*}, p<0.01 ; N S$, non-significant

Feed conversion appeared to improve with increasing level of dietary inclusion of palm oil. The best feed conversion of 1.51 was obtained from $4 \%$ palm oil and it was better $(p<0.05)$ compared to the group on 0,2 and $3 \%$ at 2 nd week of age. Nwoche et al. (2003) found similar results in their experiments. During the entire trial a trend of improving FC was observed with the increasing level of dietary palm oil having the exception at 5\% level as compared to without oil. This result is in agreement with Panja (1996) who reported that the performance of broiler with different levels of palm oil $(2,4,6$ and $8 \%)$ and found broilers fed on higher energy diets had improved feed conversion.

Table 5. Feed conversion of broiler fed different levels of palm oil

\begin{tabular}{llllll}
\hline $\begin{array}{l}\text { Age } \\
\text { (wk) }\end{array}$ & \multicolumn{5}{c}{ Dietary treatments $^{1}$} \\
\cline { 2 - 6 } & Control & $2.0 \% \mathrm{PO}$ & $3.0 \% \mathrm{PO}$ & $4.0 \% \mathrm{PO}$ & $5.0 \% \mathrm{PO}$ \\
\hline 1 & 1.71 & 1.59 & 1.52 & 1.54 & 1.53 \\
2 & 1.56 & 1.58 & 1.54 & 1.51 & 1.55 \\
3 & 1.77 & 1.78 & 1.74 & 1.65 & 1.93 \\
4 & 1.98 & 2.08 & 1.96 & 2.04 & 1.77 \\
5 & 2.21 & 2.05 & 2.31 & 2.36 & 2.17 \\
Cumulative feed conversion & & & \\
1 to 4 & 1.79 & 1.83 & 1.75 & 1.78 & 1.73 \\
1 to 5 & 1.91 & 1.87 & 1.91 & 1.88 & 1.89 \\
\hline
\end{tabular}

$P O$, palm oil; values are not differed significant 


\section{Palm oil in broiler feed}

Yield of different and portions of broiler meat is presented in Table 6 . The meat yield characteristics did not differ ( $p>0.05)$ among the broilers of receiving different levels of palm oil in diets except gizzard, wing meat and dark meat. Data in the table showed that the increasing level of oil gave $(p<0.01)$ and progressive decrease in gizzard weight of the broilers in different groups. Supplementation of oil at different levels resulted in increase $(p<0.05)$ in wing meat weight at $3 \%$ oil supplementation. Also, supplementation of oil resulted in significantly $(p<0.05)$ increased dark meat weight at $3 \%$ level. Dressed yield of broilers had an increasing trend at increased level of palm oil supplementation up to $4 \%$. However, $5 \%$ supplementation dressed yield was lowest. Similar results were also observed in breast meat. Thigh meat was progressively increased for supplementation of oil up to $3 \%$ level, higher level it tended to be decreased.

Table 6. Meat yield characteristics of broilers

\begin{tabular}{|c|c|c|c|c|c|c|}
\hline \multirow{3}{*}{ Parameter } & \multicolumn{5}{|c|}{ Dietary treatments } & \multirow{3}{*}{ Sig. } \\
\hline & \multirow{2}{*}{ Control } & $2.0 \%$ & $3.0 \%$ & $4.0 \%$ & $5.0 \%$ & \\
\hline & & Palm oil & Palm oil & Palm oil & Palm oil & \\
\hline Live wt. & 1770.33 & 1837 & 1812 & 1838 & 1787 & NS \\
\hline Dressed wt. & 90.87 & 91.46 & 91.99 & 91.97 & 90.14 & NS \\
\hline Total meat wt. & 34.03 & 32.09 & 34.01 & 30.08 & 31.94 & NS \\
\hline Breast meat wt. & 15.441 & 13.21 & 13.91 & 14.24 & 13.60 & NS \\
\hline Dark meat wt. & $17.74^{b}$ & $17.99 \mathrm{~b}$ & $20.16^{a}$ & $17.74^{b}$ & $17.12^{\mathrm{c}}$ & * \\
\hline Breast dark meat & 0.87 & 0.73 & 0.69 & 0.81 & 0.80 & NS \\
\hline Thigh meat wt. & 9.25 & 9.54 & 10.34 & 8.92 & 8.59 & NS \\
\hline Drumstick meat wt. & 5.80 & 5.66 & 6.29 & 5.73 & 5.47 & NS \\
\hline Wing meat wt. & $2.70^{c}$ & $2.80^{c}$ & $3.53^{\mathrm{a}}$ & $3.09 \mathrm{~b}$ & $3.06^{b}$ & * \\
\hline Abdominal fat wt. & 1.40 & 1.92 & 2.09 & 2.23 & 2.22 & NS \\
\hline Liver wt. & 2.61 & 2.90 & 2.77 & 2.66 & 2.71 & NS \\
\hline Heart wt. & 0.49 & 0.52 & 0.55 & 0.53 & 0.56 & NS \\
\hline Gizzard wt. & $2.09 a$ & $1.89 \mathrm{~b}$ & $1.56^{\mathrm{bc}}$ & $1.65^{b c}$ & $1.38^{c}$ & ** \\
\hline Thigh bone wt. & 1.50 & 1.34 & 1.47 & 1.34 & 1.42 & NS \\
\hline Drumstick bone wt. & 2.22 & 1.92 & 1.99 & 2.03 & 2.17 & NS \\
\hline Wing bone wt. & 1.96 & 1.92 & 1.99 & 2.07 & 2.01 & NS \\
\hline Skin wt. & 8.87 & 9.34 & 8.46 & 9.98 & 8.95 & NS \\
\hline Head wt. & 2.49 & 2.52 & 2.48 & 2.47 & 2.56 & NS \\
\hline Neck wt. & 1.92 & 1.85 & 1.80 & 1.81 & 1.98 & NS \\
\hline Shank wt. & 4.29 & 4.27 & 4.28 & 3.83 & 4.26 & NS \\
\hline Feather wt. & 4.92 & 4.29 & 3.92 & 4.23 & 4.33 & NS \\
\hline Blood wt. & 4.21 & 4.25 & 4.08 & 3.80 & 5.53 & NS \\
\hline Digestive tract wt. & 6.59 & 6.73 & 6.82 & 6.56 & 6.64 & NS \\
\hline
\end{tabular}

Means with different superscript(s) in the same row differed significantly; NS, non-significant; *, p $<0.05$, $* *, \mathrm{p}<0.01$

The weight of liver and heart of the broilers were slightly increased for supplementation in those diets. Dietary supplementation of palm oil in broiler feeding resulted in non-significant increase in abdominal fat content of broilers. Similar results were also found in case of skin, head and neck of broilers. The data on meat yield characteristics indicated that the total meat yield decreased for supplementation of oil in the diet of broilers. In the present study, the breast meat yield decreased compared to without oil. However, the dark meat yield increased which is in agreement with the findings of Mendes et al. (2004) but differed with the findings of Bobadoye et al. (2008). On the other hand, abdominal fat percentage, skin and digestive tract weight increased as the level of oil increased. However, meat yield and breast meat was similar among treatments $(p>0.05)$. The relative meat yield (breast: dark meat) decreased as oil level increased because of depleting breast meat and replacing dark meat as the level of oil increased. The dark meat yield consists of the total of thigh meat, drumstick meat and wing meat of which the thigh meat and the wing meat increased as the level of oil increased. This implies that the protein accretion in the thigh and wing increased with the level of oil increases.

The result showed that the heart weight slowly increased $(p>0.05)$ almost in a linear fashion as the level of oil increased. This might be the result of high fat deposition around the pericardium of the heart which might have implications on the dystolic and systolic system of the heart of the chickens (Agbede and Aletor 1997). Present study also showed that the relative gizzard weight decreased significantly as the oil level increased which is in agreement with Bobadoye et al. (2008) but not at significant level. The abdominal fat accumulation increased with the increasing level of oil which agreed with Bobadoye et al. (2008) and suggested that inclusion of palm oil in the diet of broiler would promote fat deposition in broiler carcass.

There was a positive numerical relationship between lean meat yield and FC irrespective of all dietary treatments. As the amount of lean meat yield increased FC also increased simultaneously. The stimulation for efficient utilization of diets supplemented with palm oil has been reported by different researchers. Palm oil promotes the intestinal uptake of amino acids, even when the amino acids are present as a mixture, by 
modifying the intestinal epithelium for better uptake (Abaelu et al. 1991). In terms of absorbed amino acids, palm oil improves the metabolism of the sulphar containing amino acids (Umoh et al. 1983). As a result, growth rate as well as FC tends to improved with decreasing trend of lean meat yield.

\section{Conclusion}

Up to $4 \%$ level of palm oil in broiler diets found to have increasing effect on weight gain as well as FC. However, it has decreasing effect of lean meat yield. High level (5\%) of palm oil supplementation has depressing effect on live weight gain and feed intake.

\section{References}

Abaelu AM, Okochi VI, Oyesile OO, Akinyele JO, Akinrimisi EO (1991). Nigerian dietary oils and transport of amino acids in rat intestine. Nigerian Journal of Physiological Sciences, 7: 32-37.

Agbede JO, Aletor VA (1997). The performance, nutrient utilization and cost implication of feeding broiler finishers conventional or underutilized feed resources. Applied Tropical J ournal, 2: 57-62.

AOAC (1997). Official Methods of Analysis. Vol. I. $15^{\text {th }}$ Ed., Association of Official Analytical Chemists, Arlington, VA.

Bobadoye AO, Onibi GE, Fajemisin AN, Olasupo OO, Bobadoye BO (2008). Replacing Maize with Palm Oil Sludge in Broiler Chicken Diets: Effect on Carcass Characteristics, Organ Weight and Muscle Development. International Journal of Sustainable Crop Production, 3: 1-5.

Duncan D.B. (1955). Multiple range and multiple ' $F$ ' test. Biometrics 11, 1-42.

Franco SG, Junqueira OM, Fedalto $L M$ and Paulillo AC (1995). Effects of feeding programs and the addition of oil, in different phases, on the development of broiler chickens. Revista-do-Setor-de-CienciasAgrarias, 14: 95-102.

Gomez AK, Gomez AA (1984). Statistical procedures for Agricultural Research. $2^{\text {nd }}$ Edition, J ohn Willy and Sons, New York.
Hake HM, Mehmet A, Anitha B, Moorthy M, Nididi $\checkmark$ (2005). Effect of various Dietary Fat Sources on Performance and Body Fatty Acid Composition of Broiler Chickens. Journal of Animal and Veterinary Advances, 6: 1317-1322.

J ones R (1984). A standard method of dissection of poultry for carcass analysis. Technical Bulletin No. 222, West of Scotland Agricultural College, Scotland.

Mendes AA, Moreira J, Oliveira EG de, Garcia EA, Almeida MIM de, Garcia RG (2004). Effect of dietary energy on performance, carcass yield and abdominal fat of broiler chickens. Revista Brasileira de Zootecnia, 33: 23002307.

Nwoche GN, Ndubuisi EC, Iheukwumere FC (2003). Effects of dietary palm oil on the performance of broiler chicks. International Journal of Agricultural and Rural Development, 4: 81-86.

Olorede BR, Longe OG (1999). Evaluation of molasses and palm oil in broiler chicken diets containing high level of shea butter cake. Journal of Sustainable Agricultural Environment, 1: 172-177.

Panja P (1996). Effects of Supplementation of Palm Oil in Isonitrogenous Diets on Broilers. Thammasat I nternational J ournal of Science and Technology, 1: 47-54.

Rahman M (2000). Bangladesh poultryman need help, Production, processing and marketing world wide, Poultry International, 39: 15.

Singh RA (1980). Poultry Production. 3rd Ed., Kalyani Publishers, 102b, Ramanath Mazumder Street, Ballygunj, Kolkata, 700019.

SPSS. (2007). SPSS for Windows, Version 16.0, SPSS Inc, Chicago.

Stata (2009). Stata Statistical Software, Version 11C, TX: StataCorp LP., College Station, USA.

Umoh IB, Ayalogu EO, Oke OL (1983). Effect of different levels of palm oil and sulphur in cassava-based diets. Food Chemistry, 10: 83-95. 